tion by prismatic ice-crystals at high elevations, the parhelia always appear on the horizontal parheliacal ring which passes through the centre of the sun, and generally at the intersection of this ring with the vertical halo. The two parhelia must therefore always lie in a line parallel to the horizon, and at the same elevation as the sun itself. The same laws regulate the appearance of the paraselenæ or mock moons. It therefore surprised me to learn that the left-hand mock moon appeared at a greater distance from the horizon than the right-hand one. It seemed to me to be "unaccountably out of place." That the circle should have subtended an angle of $50^{\circ}$, as stated by "Sm.," is in itselt unusual. The normal diameter is understood to be from $44^{\circ}$ to $47^{\circ}$. Did "Sm." actually measure it? To my judgment it was considerably more than this, but of course mere estimates are not trustworthy. I do not see how a " change of level of the refracting cloud "should alter the position of the mock moons. This must depend upon the relative positions of the moon and the observer's eye. If the cloud is not in the right place no mock moons will be seen. I should be glad of a satisfactory explanation of the phenomenon recorded.

Birstal Hill, Leicester, May 7

F. T. Mot'T

REFERRING to a letter from Mr. F. T. Mott in NATURE, vol. xxvii. p. 606, I find that at midnight on April 16 the moon's apparent altitude at Leicester was not more than $26^{\circ}$; so that after allowing for the difficulty of seeing the actual horizon, and taking also into account the breadth of the halo, it seems improbable that the halo observed by Mr. Mott was of unusual size.

I have, however, seen a description somewhere of a parhelion - measured with a sextant about the end of last century-which had a semidiameter of $26^{\circ}$. It would be interesting to know whether such irregularities in the dimensions of these phenomena have been accurately ascertained.

19, Catherine Street, Liverpool

R. C. JOHNSON

\section{Sun Pillar of April 6, 1883}

IT may be of interest to record the various points from which the above phenomenon was seen. I was at St. David's with a party of geological students, and we watched it for some time as we were returning from the coast at sunset.

Cambridge

Thos. McKenny Hughes

\section{Fibreballs}

I READ with much interest the letters of Prof. G. H. Darwin and "J. H.," NATURE, vol. xxvii. pp. 507, 580. On the coast of South Australia, especially on the Coorong beach, I have seen fibreballs in great quantity; some larger than a cricket ball, and perfectly spherical, hard, and well-matted; others tapering and having the form of an exceedingly long ellipse. I brought home many specimens. These are now in the Wragge Museum at Stafford; and I shall be happy to have some forwarded for Prof. Darwin's inspection.

Fort William

Clement L. Wragge

\section{Helix pomatia}

ONLY a few more lines to say, in consequence of the communication of Mr. Stokoe in your last number (p. 6), that he will find the mollusca in their geological relations treated in the introduction to my work on "British Conchology," vol. i. p. cix. The distribution of $H$. pomatia in this country and on the Continent is noticed in pp. 177 and 178 of that volume, and in the supplement to the fifth volume.

I, The Terrace, Kensington, May 4

J. GWYN JEFFreys

I HAVE fourd this freely in the hedge-tottoms of Hertfordshire lanes, where the soil was a dark alluvial mould, certainly not cretaceous. I suspect that even in its known localities it is very local.

Bregner, Bournemouth, May 5

HENRY CECIL

In two of the localities mentioned for this snail-Dorking, Surrey; and Woodford, Northamptonshire-there seems some reason to suspect it to be a modern introduction. From 1849 to 1852 I lived within two miles of Woodford, and often found the shells in a smail wood known as Woodford Shrubbery. It was commonly said in the neighbourhood at that time that the snails were brought from abroad by the gentleman-I think General Arbuthnot-who had formed the Shrubbery some thirty years before that date.

I also found, many years ago, shells of the same species about the foot of Box Hill, near Dorking, and was told by a former resident in that neighbourhood that the snails were brought from Italy by Mr. Hope, of Deepdene, who was well known in the early part of this century as a u riter on the mediæval architecture of Italy. I give the statements for what they may be wcrth.

Loughton

J. C.

\section{Intelligence in Animals}

IN addition to the long list of "emotions which resemble human intelligence as occurring in animals below the human species," as given by your correspondent on the authority of Dr. Romanes (NATURE, vol. xxvii. p. 580), and the instance of "benevolence" subsequently cited, I venture to submit the following as illustrating something very like the emotion of contempt.

Until recently our domesticated animals included two cats-one a very fine tabby (a trimmed male) of somewbat morose nature, and a pretty little black cat, a half-bred Persian (a female) of very gentle character. On a noticeable occasion the tabby cat caught a mouse and ate it all up with much relish in a corner of the room. The proceeding was watched with much interest by the black cat from her place on the hearthrug. After the tabby had finished his repast he also took up his place on the hearthrug. The black cat then went over and smelled the spot where the dainty morsel had been devoured. Upon this the tabby cat came up and "boxed" the black cat's ears once or twice, as who should say, "What busine: $s$ have you with my affairs? catch your own mice!"

Handsworth Wood, near Birmingham, May 5

MAY I contribute another case of higher thought in the lower animals. At the farm of Granton Mains, near Edinburgh, an old cat had become blind; her daughter had kittens. The daughter was observed bringing in a sparrow to the boiler-house, where her blind mother and her half-grown kittens were warming themselves: the kittens came up to get the sparrow, but their mother kept them off and gave the sparrow to her mother, and watched whilst she ate it. She was frequently seen to give other food to her blind mother.

My children have a fox terrier bitch, "Dot." Dot loves to kill anything from a cat to a mouse, and sometimes a wild rabbit gets into the garden, and it is a red-letter day for Dot and the children. But the children have also tame rabbits; of cour: $e$ any one who knows dogs will understand that it is simple to teach them not to touch pets-for instance, the cat of their own house. But Dot had a curious case to decide. The children had found a nest of wild rabbits, and two of the tame rabbits (black and white) had made a hole in a bank and there had young ones. This nest was respected by Dot. The children took the young wild rabbits (gray) and fostered them on the tame ones by slipping them into the nest. A few days after this, Dot must bave discovered these gray young ones with the black and white. Had she found them anywhere else, one snap, and they were dead; tut this was the line she took: she was found at the front door under the porch with one of the young gray rabbits, quite fifty yards from the nest; it was quite unhurt, although it died afterwards, I believe from cold and exposure at the time. Are we to suppose that Dot wished to ask the question, "May I kill this gray one?" DUnCAN STEWART Knockrioch, May 2

\section{HE SOLAR ECLIPSE OF 1883}

$T$ HIS eclipse, as our readers have already been made aware, took place on Sunday last, and we may hope, although we shall not know for more than a month, that the weather was favourable. We shall not hear whether the French arrived in time, but we do know that the English observers met the American party, consisting of Prof. Holden, Dr. Hastings, Mr. Rockwell, Mr. Preston, 